\title{
Market research in Metepec, State of Mexico to determine the acceptance of an artisan soap made from corn
}

\section{Investigación de mercado en Metepec, Estado de México para determinar la aceptación de un jabón artesanal elaborado con base de maíz}

\author{
ZENTENO-BONOLA, Ana Luisa $\dagger^{*}$, AGUIRRE-BRITO, Dorian, CERVANTES-CARBAJAL, Ana \\ Margarita and GARCÍA-BARRUETA, Katia Guadalupe
}

Tecnológico Nacional de México/Instituto Tecnológico de Toluca, Mexico.

ID $1^{\text {st }}$ Author: Ana Luisa, Zenteno-Bonola / ORC ID: 0000-0003-3634-588X, CVU CONACYT ID: 16B709-213685

ID 1 ${ }^{\text {st }}$ Coauthor: Dorian, Aguirre-Brito / ORC ID: 0000-0002-3642-4767, CVU CONACYT ID: IT16B446-998086

ID $2^{\text {nd }}$ Coauthor: Ana Margarita, Cervantes-Carbajal / ORC ID: 0000-0002-0877-4145, CVU CONACYT ID: IT16E0281058664

ID $3^{\text {rd }}$ Coauthor: Katia Guadalupe, García-Barrueta / ORC ID: 0000-0002-3338-6953

DOI: $10.35429 / J B A B \cdot 2020.6 .4 .1 .15$

Received January 10, 2020; Accepted June 30, 2020

\begin{abstract}
Currently there are some skin diseases that have increased their appearance in people, mainly due to environmental pollution. According to some research, it is known that at 18 years of age, people have accumulated $70 \%$ of the chronic actinic damage that will manifest itself with some skin condition in adulthood. Certain scientific studies demonstrate the beneficial properties of the corn plant in relation to skin conditions, so the development of an artisan soap based on this plant was proposed. The objective of this work was to apply a study that allowed determining the acceptance of this soap in Metepec, México. The type of research was quantitative and descriptive in scope. The market study process was carried out by Zikmund (2009) considering the following stages: Definition of the objective, Planning of the design and the sample, Collection, processing and analysis of the data and Formulation of the report. The results were: $90 \%$ acceptance of the product, elaboration in pastel colors, with relaxing aromas, stick, oval in shape and a size of 160 grams. Respondents aware of the environmental problems that exist, prefer biodegradable packaging.
\end{abstract}

\begin{abstract}
Resumen
En la actualidad existen algunas enfermedades de la piel que han incrementado su aparición en las personas, debido principalmente a la contaminación ambiental. De acuerdo con algunas investigaciones se sabe que a los 18 años las personas han acumulado $70 \%$ del daño actínico crónico que se manifestará con alguna afección en la piel en la edad adulta. Ciertos estudios científicos demuestran las propiedades benéficas de la planta de maíz en relación a los padecimientos de la piel, por lo que se propuso la elaboración de un jabón artesanal con base en esta planta. El objetivo de este trabajo fue aplicar un estudio que permitió determinar la aceptación de este jabón en Metepec, México. El tipo de investigación fue cuantitativa y alcance descriptivo. El proceso del estudio de mercado fue de Zikmund (2009) considerando las siguientes etapas: Definición del objetivo, Planeación del diseño y de la muestra, Recolección, procesamiento y análisis de los datos y Formulación del informe. Los resultados fueron: aceptación del producto en un $90 \%$, elaboración en colores pastel, con aromas relajantes, en barra, de forma ovalada y un tamaño de 160 gramos. Los encuestados conscientes de los problemas ambientales que existen, prefieren un empaque biodegradable.
\end{abstract}

Jabón, Maíz, Piel artisan soap made from corn. RINOE Journal-Business Administration-Marketing; Accounting. 2020. 4-6:1-15.

\footnotetext{
* Correspondence to Author (Email: azentenob@toluca.tecnm.mx)

$\dagger$ Researcher contributing first author.
} 


\section{Introduction}

As of today, in Mexico there is no culture of skin care. It is estimated that children spend 2.5 to 3 hours in the sun daily and may receive more ultraviolet B (UVB) radiation per year than adults. Several studies even show that the regular use of protective products before 18 years of age can reduce the incidence of some skin disease up to $78 \%$ (Jurado, 2011).

For this reason, it was proposed to make a corn-based artisan soap, since it has been shown in various studies that it provides antioxidants that help prevent cell degeneration or death, as well as helping in hydration and nutrition of the skin. And since it is made by hand, no preservatives are used and its ingredients are completely natural.

The objective of this work was to develop a market research that allowed to determine the acceptance in the population located in Metepec, State of Mexico of the artisan soap made with corn base for skin care.

The stages that were used are those established in the book on Market Research by William Zikmund and Barry Babin (2009), being the following: Definition of the objective, Planning of the design and the sample, Collection, processing and analysis of the data and Formulation Of the report.

The sections that make up this research are: frame of reference, where the antecedents, theoretical foundations and an approximation of the object of study are addressed, subsequently the approach of the problem is described, the methodology used is detailed, the results are exposed and the conclusions are presented.

\section{Framework}

In this part, the elements that make up the article will be broken down: soap, corn and market research. As the first section, the history of soap aimed at its use for personal hygiene, highlighting the artisanal production. In another section, the main ingredient that is corn will be detailed and closes with an outline of the market research structure. We have inherited the term soap from the Latin sapo (saponis), although the Spanish version came from the accusative form saponem.
Quillahuaman (2018). According to some chroniclers, they indicate that in the ancient Sumerian civilization soap was mentioned in some writings in $3,000 \mathrm{BC}$ in Mesopotamia. Then an Egyptian papyrus from 1,500 BC. C. evaluated as "legitimate medical treatment" used some soapy essences used to clean the body with linen and cotton in the treatment of skin diseases. Later, it was spreading through trade between cultures, through conquests; By records of the time, we can indicate that soap reached the Persians, Greeks and Romans, who spread the use of it on a daily basis.

Abud (2004). He mentions in his book that Galen, the most important of the Roman doctors, claimed that it was the best way to eliminate the main source of disease: dirt. $\mathrm{He}$ points out that the Germans and the Celts used goat fat and birch ash to make their soap. And it narrates other antecedents: in the third century BC. in Arabia they made their soap with the mixture made of potash, alkali, sesame oil and lemon. By the 8th century it was already known throughout southern Europe, it was manufactured in Toledo, Genoa, and Marseille, making it with wood ashes and animal fat. At the beginning of the 10th century, the first European soap dish was built by the Arabs, in Seville, Spain, in the Guadalquivir Valley; This soap 25 years later would be known as castile soap, arriving in the United Kingdom at the end of the 10th century, its ingredients came from vegetable oils. During the fourteenth century the first soap factories were established, making them an entire industry, where the way of making them changes radically, since they go from being done manually to making them, using more scientific methods.

In 1791, the Frenchman Nicolás Leblanc, discovered the way to obtain soda from common salt, coal, chalk and glauber's salt, being a cheap procedure to which he supplied soda for the market and which consequently made soap making cheaper, since Before the soap industry, only wood ashes and potassium carbonate were used to obtain its raw material. In 1820, the Frenchman Michel Eugene Chevreul, discovered olein, showing that soap was the result of a precise chemical relationship, making his soaps using beef tallow subjected to temperatures of between 80 and 100 degrees by means of soda lye, of which He obtained a mixture of soap that he dried with common salt. 
In 1861, the Belgian Ernesto Solvay added ammonia and carbon dioxide to a solution of sea salt, being one of the definitive formulas for making soap. In 1903 the German Adolph Krupp, with his famous refrigerated press to make soap, gave a great turn to the production of soap for personal use, where the procedure facilitated the rapid solidification of hot and liquid soap, through a cooling process by water, so it was easy to divide the blocks or portions of the size that you wanted the soap mass, put a seal and prepare them for packaging and packing.

Rule (2014). In Mexico, the soap industry is one of the oldest, the pre-Hispanic cultures used the copalxocolt herb (called the soap tree by the Spanish) and the xiuhmaolli root, which they used as soap for personal hygiene, since both ingredients generated bubbles; They were very careful in personal hygiene, this hygiene had an impact on the Spanish. By 1575 a soap dish was built in Mexico City where soaps were made with tequesquite, a mineral rich in soda, and were complemented with some flowers or plants. The history of soap over time became a consolidated industry. Over the years, several companies developed soaps for cleaning for personal use, with the 1920s and 1930s standing out, due to the fact that they offered personal care products that were preferred by consumers, taking care of efficiency levels to obtain quality products with great performance and at a fair price; It is worth mentioning that some of the traditional soap manufacturing companies of that time, which made soaps for personal cleaning, began to manufacture handmade soaps; many of them made with the same recipes, with the same processes and even using the same old machinery.

To date, in Mexico, there are companies that started operations at the end of the last century. The soap industry has been congregating around the National Chamber of Oils, Fats and Soaps for more than half a century, convened on March 24, 1944 by an Assembly of representatives of the fifty-nine companies in the field, organized by: Mr. Esteban González Padilla, from the "La Corona" Soap Factory; Mr. Luis Gutiérrez Sola, from the "La Rosa" Oil Factory and Mr. Salvador Herrera, from the "El Clavel" Edible Oils and Fats Factory, the purpose of the Assembly was the constitution of the Chamber; In the 1950s, these organizations began to market powdered detergents, cleaning products and dishwashers in Mexico.
In the 90's, there is a breakthrough in the development of detergents. It was then that, with the entry into force of the new Law on Business Chambers and their Confederations, in January 1977, the code corresponding to the manufacture of detergents was authorized within the Business Information System (SIEM), in September of the same year. , the then Secretary of Commerce and Industrial Development authorizes the change of name that currently prevails: National Chamber of the Industry of Oils, Fats, Soaps and Detergents (CANAJAD), which represents industrial sectors such as: manufacture of edible oils and fats, soaps, detergents, toothpastes, flavoring cleaners, and the like. With representation throughout the Mexican Republic and published in the Official Gazette of the Federation on June 30, 1998.

The mission of CANAJAD is to group and represent the affiliated industries in an efficient and ethical way, in order to strengthen the competitiveness of the represented sectors and promote the development of the national industry. Its vision is to be an inclusive Chamber; active nationally and internationally; that positively influences the transformation processes of the country, promoting the environment. Its values are: Integrity, Respect, Responsibility, Inclusion and Diversity. And within its main objectives are to represent the affiliated industries, the competitiveness of the represented sectors and promote the development of the national industry, being active in the international arena and positively influencing the transformation processes of the country, promoting care of environment.

Ochoa (2016). The products of the national industry of soaps for personal use supply $100 \%$ of the national market, through a wide range of presentations, varieties, types and brands. Currently, $79.5 \%$ of the installed capacity of the sector uses modern technologies by virtue of which the quality of its products is high, this has allowed it to offer competitive prices both in Mexico and abroad.

In recent years, the demand for the products has grown steadily, due to the increase in the total population of the country. Toilet soap is commonly used in homes, with $85 \%$ market penetration. 
Among the main national soap producers are the states of: Guerrero, San Luis Potosí, Hidalgo, Jalisco, Yucatán, Michoacán, Mexico City, Guanajuato, Nayarit, Veracruz, Puebla, Nuevo León and the State of Mexico. In the latter, the municipalities of Ecatepec, Nezahualcóyotl and Valle de Bravo are found as producers of artisan soap.

Barbosa (2012). At present, there is knowledge of different types of soap that are used daily, not only because of their smell or appearance, but also because of their priorities and they can be:

- Common soaps: These are solid and foamy, made with fatty tallow and sodium or potassium. They are indicated for all skin types and in some cases can be used to wash hair.

- Dermatological soaps: They contain cleaning agents, very mild synthetics, to which vegetables are added that help to close the pores, relieving irritations and stopping the appearance of acne or blackheads. With these soaps the skin does not flake. They are recommended for skin that has problems, either permanently or seasonally, or in the event of specific appearances of irritations.

- Glycerin soaps: They are neutral, they do not usually moisturize the skin, on the contrary, on some occasions they tend to dry out them and are recommended for oily skin. In general, glycerin has a longer lasting effect than ordinary soaps.

- Therapeutic soaps: They are prescribed by doctors, some are recommended for psoriasis, for cutaneous mycosis and others for deep cleansing of the skin.

Aromatic soaps: They are used by the majority, they are those to which flower or fruit essences are added, not recommended for sensitive skin or allergy sufferers. They also have a relaxing effect in some cases, depending on the floral essence they contain.
Barbosa (2012). The vast majority of soaps for personal use currently available are manufactured industrially on a large scale by means of procedures that seek to lower costs and obtain the greatest benefits from the raw materials used and from the extracted byproducts. This results in the soap thus obtained being, in most cases, a reconstituted product. Soap should not only effectively cleanse the skin, but also help to moisturize, nourish it and prevent allergic reactions and irritations. It is for this reason that the production of artisan soap is being implemented today, these are natural products that, properly selected and dosed, improve the properties of the soap and preserve the aroma of its base ingredient.

They are products that are made by hand, from methods that use simple or mechanical tools for their production in a non-industrial way. The chemical reaction from which these soaps are made is saponification. A fat is mixed with sodium or potassium hydroxide to obtain them, the techniques by which this reaction is triggered can be hot or cold, depending on the ingredients used. Essential oils or artificial fragrances can also be used to give the soap an odor and natural or artificial colorants are used to color it, it is important to mention that they do not use preservatives. Industrial soap on average lacks both unsaponifiable substances and glycerin. These elements that are not in industrial soaps are important for the skin, because they help in its hydration and nutrition.

As for the key ingredient, corn, there is a variety of studies that demonstrate its attributes in reference to skin care. Alba (2016). Genetic, paleobotanical and archaeobotanical studies carried out to date indicate that the Zea mays (corn) species is a grass native to Mexico, from where it spread throughout the American continent. Later, while it dispersed, it adapted to different climates, environmental characteristics, altitudes and tastes of the inhabitants. The oldest dates found and calibrated to date correspond to 8990 to 8610 $\mathrm{BC}$, and come from the Xihuatoxtla rock refuge, in the north of the current state of Guerrero, where they were found and carried out studies with corn and pumpkin phytoliths. These are the oldest evidence found in relation to the Mesoamerican origin of cultivated corn, although we must consider the few similar studies, in depth and methods, for other parts of the continent. 
In Mexico, as in the rest of Latin America, corn represents an indispensable cultural element of universal validity and an irreplaceable and main ingredient in the diet of Mexicans, constituting a basic food of the population that consumes it in various forms (tortillas, tamales, drinks). Likewise, the native population attributes to corn various medicinal properties in the treatment of infections, kidney diseases and cancer treatment.

Álvarez (2013). Recently, it has been considered that the pigments of corn grains (Zea mays), in addition to their use as natural colorants, have antioxidant activity, therefore their nutritional interest due to their contribution to the maintenance of human health due to the beneficial properties of their secondary metabolites ; In addition to carotenoids, anthocyanidins are present in appreciable quantities in pigmented varieties of corn, giving them antioxidant activity and making corn a potential product for the supply of natural colorants and antioxidants.

That is why corn is considered one of the main ingredients in the handmade soap that is intended to be made. On the other hand, corn also contains salicylic acid, an element to which sedative, analgesic, anti-haemorrhagic properties are attributed; countless soaps include derivatives of this grass as part of their formulation. These properties will have the skin when using corn soap. To protect the skin from dryness, corn oil is rich in carvacrol, thymol and menthol, which helps both normal and dry skin. It is also rich in vitamin B7 (biotin), vitamin $\mathrm{K}$, niacin, folic acid and lots of vitamin $C$, in the form of becarotenes, unlike other cereals that contain little significant amounts of this element. It also contains high percentages of potassium, magnesium, iron, phosphorus, selenium, and zinc.

The purpose of this study is to investigate the acceptance in Metepec, State of Mexico of an artisan soap based on corn. There is a diversity of proposals to develop market research. Some will be examined.

Nuñez (1997). The objective of the market study is to determine the acceptance of the service or product considered, which can be expected to be attended by the project when it enters into operation.
To reach this objective, the designer, that is, those who prepare the study, must consider the following questions in their analysis:

- $\quad$ The demand.

- $\quad$ The offer.

- $\quad$ The supply - demand balance.

- $\quad$ Prices or rates.

- $\quad$ The marketing and distribution system.

- Complementary services or supports.

Moyano (2016). At any level, to carry out a market study the following steps should be considered:

- $\quad$ Definition of the objective.

- $\quad$ Analyze the situation.

- Informal research.

Formal research: surveys, observation, qualitative research (focus group) and quantitative survey (questionnaire).

- Data analysis and real report.

- Segmentation.

- Positioning.

- $\quad$ Added value.

Outline the market objectives.

Prieto (2009). The proposed procedure for market research is:

- Diagnosis of the current situation of the company.

- Preparation of the data collection instrument.

- Data collection.

- $\quad$ Basic elements of statistics and sampling.

- $\quad$ Field work.

Administrative aspects.

ZENTENO-BONOLA, Ana Luisa, AGUIRRE-BRITO, Dorian, CERVANTES-CARBAJAL, Ana Margarita and GARCÍABARRUETA, Katia Guadalupe. Market research in Metepec, State of Mexico to determine the acceptance of an artisan soap made from corn. RINOE Journal-Business Administration-Marketing; Accounting. 2020 
- $\quad$ Analysis and interpretation of data.

- $\quad$ Market research report.

Fernández (2004). The process of a market study consists of the following stages:

- Initial approach.

- $\quad$ Group meeting and in-depth interview.

- $\quad$ Projective techniques and observation.

- $\quad$ Survey.

- $\quad$ Sampling and field work.

- Multivariate analysis and report preparation.

The process that was applied to the present investigation is the one proposed by the authors William Zikmund and Barry Babin. Which is explained later.

\section{Problem Statement}

A major issue today is skin care, which includes the aesthetic aspect, but also that of health. The latter is extremely important because carelessness has serious consequences for human beings. There are diverse and deep investigations regarding what it means to take care of the skin to avoid any skin disease.

The National Institute of Statistics and Geography (INEGI) has the following classification in relation to skin diseases:

- Infections of the skin and subcutaneous tissue, such as: Cellulitis, Impetigo, Skin abscess, Furuncle and carbuncle, Acute lymphadenitis, Pilonidal cyst, Pyoderma, Erythrasma, among others.

\section{Dermatitis and eczema.}

Other skin and subcutaneous tissue disorders.

Another disease that unfortunately can also develop due to a variety of factors is skin cancer. Jurado (2011) comments in her article that sun exposure is decisive in the development of skin cancer, especially intense and intermittent sun exposure during childhood and adolescence.
Jury (2011). It is estimated that children spend 2.5 to 3 hours in the sun daily and may receive more ultraviolet $B(\mathrm{UVB})$ radiation per year than adults. Several studies even show that the regular use of sunscreens before 18 years of age can reduce the incidence of skin diseases by up to $78 \%$. It is currently known that by age 18 , $70 \%$ of the chronic actinic damage that will manifest itself in adulthood, such as photoaging or other conditions, has accumulated, so it is important to start skin care measures from childhood.

In Mexico there is no culture of protection and there are many myths regarding the use of sunscreen. Most of the Mexican population is unaware of the harmful effects of prolonged exposure to solar radiation.

Gutiérrez (2003). It emphasizes that skin diseases have increased their frequency in recent years worldwide. In Mexico there is an underreporting of cases, since most of them do not cause mortality and many are treated immediately without there being a confirmatory study.

Díaz (2011). It establishes that although exposure to ultraviolet radiation (UVR) has been identified as the most important risk factor for the development of skin diseases; the environment, the habits of recreation and care, as well as the inheritance also contribute to its development.

The Mexican Social Security Institute (IMSS) recognizes that the cases of dermatitis have increased and among the main causative agents that cause it are contact with soaps and detergents, disinfectants, alcohol, cosmetics and fragrances, solvents, among others. This leads to a problem that is intended to be alleviated with the proposal of an artisan soap made from corn, which, although it does not solve or stop any of the skin diseases described, does manage to take care of it and can act with a preventive nature, since it does not contain parabens, silicones or other chemicals that can create irritation and even allergies; Due to the fact that it is a product with a neutral $\mathrm{pH}$, which makes it softer and more respectful of the most sensitive parts of the skin. The multiple benefits it provides is that they hydrate, nourish and prevent skin problems such as eczema or itching. It is also an alternative to traditional gels, much more respectful with the environment.

ZENTENO-BONOLA, Ana Luisa, AGUIRRE-BRITO, Dorian, CERVANTES-CARBAJAL, Ana Margarita and GARCÍABARRUETA, Katia Guadalupe. Market research in Metepec, State of Mexico to determine the acceptance of an artisan soap made from corn. RINOE Journal-Business Administration-Marketing; Accounting. 2020 
In addition, soap is a basic article of daily use that we use for personal hygiene. Hydration is necessary for the skin since it helps it to fight against the effects of the environment in the face of sudden changes in temperature and daily external aggressions in each wash.

Corn-based soap is a hydrating skin treatment. The excellence it brings is the choice of raw materials and some additives such as natural flavors that have therapeutic properties.

The objective of this work was to apply a market research that allowed determining the acceptance in the population located in Metepec, State of Mexico of the artisan soap made with corn base for skin care.

\section{Method}

The type of research that was carried out was with a quantitative approach and a descriptive scope that is used to detail the most characteristic, distinctive and particular aspects of the object of study, defining its properties. "... focuses on the questions who, what, when, where and how" according to Zikmund (2004).

Market research was applied because contact was made with end consumers (potential market) to collect relevant data regarding the artisan soap product made with corn base for skin care. It was also quantitative, because it focused on measuring concepts with scales that revealed numerical values using a structured information collection instrument through the use of a survey to obtain statistical data for informed decision making.

The process used in the present research was that of William G. Zikmund (2004) which consists of six stages, which are mentioned below:

- Definition of the research objective.

- $\quad$ Research design planning.

- Sample planning.

- Data collection.

Data processing and analysis.

Report formulation.
The stages of product description, need to satisfy and market segmentation were included, in order to suit the investigation.

\section{1) Product description}

The first point was the definition of the product, which is detailed in the technical sheet and is shown in table 1.

\section{2) Need to satisfy}

Corn soap is a personal hygiene product, which helps to clean, moisturize, purify and protect the skin in a natural way, therefore it satisfies a physiological need according to the Abraham Maslow pyramid, covering the aspect of wellbeing and health in the human body.

\section{3) Market segmentation}

The product is aimed at people who are integrated into the labor market, care about skin care and live in the municipality of Metepec, State of Mexico. Based on the basic municipal statistics bulletin issued by the Institute of Geographic, Statistical and Cadastral Information and Research of the State of Mexico (IGECEM) in 2010, the Economically Active Population (EAP) in the municipality of Metepec, State of Mexico It was 91,700 inhabitants.

\section{4) Definition of the objective of the investigation}

Know the acceptance of corn soap by people who are integrated into the labor market, care about the care of their skin and live in the municipality of Metepec, State of Mexico. For this, the information was collected during the month of September 2019.

\section{5) Planning the research design}

The working hypothesis was: Corn soap is accepted by people who are integrated into the labor market, care about the care of their skin and live in the municipality of Metepec, State of Mexico. Bernal (2016). Two variables were determined, the independent variable, which is considered as the supposed cause, or the antecedent condition and the dependent one, which is the effect or result caused by said cause. 


\begin{tabular}{|c|c|c|}
\hline \multicolumn{3}{|c|}{ Technical data sheet finished product } \\
\hline $\begin{array}{l}\text { Generic product } \\
\text { name }\end{array}$ & $\begin{array}{l}\text { Corn-based } \\
\text { soap }\end{array}$ & Code: PJM01 \\
\hline $\begin{array}{l}\text { Descripción del } \\
\text { producto }\end{array}$ & \multicolumn{2}{|c|}{$\begin{array}{l}\text { Corn-based soap is a hydrating skin } \\
\text { treatment. It is softer, does not } \\
\text { contain additional chemicals and } \\
\text { does not produce irritation reactions } \\
\text { or any other type of skin problem, it } \\
\text { contains beneficial oils that help } \\
\text { nourish the skin. }\end{array}$} \\
\hline \multirow[t]{6}{*}{ Formula } & Cornmeal & $30-40 \mathrm{~g}$ \\
\hline & Coconut oil & $0.5 \mathrm{ml}$ \\
\hline & Honey bee & $2.5 \mathrm{ml}$ \\
\hline & $\begin{array}{l}\text { Organic } \\
\text { glycerin }\end{array}$ & $250 \mathrm{~g}$ \\
\hline & Ground oats & $20 \mathrm{~g}$ \\
\hline & $\begin{array}{lr}\text { Lavender } & \\
\text { essence } & \text { or } \\
\text { various } & \text { herbal } \\
\text { essences } & \end{array}$ & $10 \mathrm{ml}$ \\
\hline $\begin{array}{l}\text { Conservation } \\
\text { type }\end{array}$ & \multicolumn{2}{|c|}{ Conservation at room temperature. } \\
\hline $\begin{array}{l}\text { Storage } \\
\text { Considerations }\end{array}$ & \multicolumn{2}{|c|}{$\begin{array}{l}\text { Store preferably in a place that does } \\
\text { not have exposure to sunlight, at } \\
\text { room temperature. }\end{array}$} \\
\hline $\begin{array}{l}\text { Applicable } \\
\text { regulations }\end{array}$ & \multicolumn{2}{|c|}{ NOM-039-SSA1-1993 } \\
\hline
\end{tabular}

Table 1 Product data sheet Source: Own elaboration

\section{Independent variable: Corn soap.}

Dependent variable: Market segment.

It was decided to build a new measurement instrument, using the procedure of Hernández, Fernández and Baptista (2003). The first step is the operational definition of the variables, which are listed in Table 2.

\begin{tabular}{|c|c|}
\hline Variable Type & Operational definition \\
\hline $\begin{array}{l}\text { Independent: } \\
\text { Corn soap }\end{array}$ & $\begin{array}{l}\text { Ingredients: } \\
\text { Corn flour, quantity } 30-40 \\
\text { grams, its contribution is } \\
\text { vitamins and minerals, } \\
\text { astringent properties to balance } \\
\text { the levels of fat in the skin, } \\
\text { facial cleanser. } \\
\text { Coconut oil, quantity } 0.5 \text { ml. } \\
\text { provides effective } \\
\text { moisturizing, helps keep the } \\
\text { skin hydrated thanks to its } \\
\text { antioxidants. Helps in the } \\
\text { treatment of dermatitis and } \\
\text { other skin infections. } \\
\text { Organic glycerin, quantity } 250 \\
\text { grams, improves skin } \\
\text { hydration, has calming effects. } \\
\text { Promotes moisture retention. } \\
\text { Ground oats, quantity } 20 \\
\text { grams, provides a cleansing } \\
\text { effect, absorbing dirt that } \\
\text { accumulates in the pores. } \\
\text { Soothing in different skin } \\
\text { infections. Avoid dehydration } \\
\text { of the skin. } \\
\text { Bee honey, quantity } 2.5 m l ., \text { Is } \\
\text { moisturizing thanks to the } \\
\text { natural enzymes it contains, it } \\
\text { is an antioxidant, regenerates } \\
\text { the skin, balances the } \\
\text { production of oil, revitalizes } \\
\text { the skin and naturally clarifies. } \\
\text { Lavender essence or various } \\
\text { herbal essences, quantity } \\
10 m l ., \text { Provides intense } \\
\text { hydration, is firming and } \\
\text { calming. }\end{array}$ \\
\hline Variable Type & Operational definition \\
\hline $\begin{array}{l}\text { Dependent: } \\
\text { Market segment }\end{array}$ & $\begin{array}{l}\text { People who are integrated into } \\
\text { the labor market, care about the } \\
\text { care of their skin and live in the } \\
\text { municipality of Metepec, State } \\
\text { of Mexico. }\end{array}$ \\
\hline
\end{tabular}

Table 2 Operational definition of variables Source: Own elaboration

Subsequently, the indicators, dimensions and items of each variable are determined. In Table 3 these elements are displayed. 
Independent variable

Indicator: product attributes (corn-based soap)

\begin{tabular}{|c|c|}
\hline Dimension & Ítems \\
\hline Elaboration & $\begin{array}{l}\text { Do you use handmade soaps? } \\
\text { A) Yes } \\
\text { b) No }\end{array}$ \\
\hline Colour & $\begin{array}{l}\text { What color range do you prefer for a soap } \\
\text { line? } \\
\text { a) Light Yellow, Green, Red, Pink, } \\
\text { Orange } \\
\text { b) Brown, black, blue, purple. }\end{array}$ \\
\hline Size & $\begin{array}{l}\text { In which presentation would you like to } \\
\text { find your soap? } \\
\text { a) } 100 \mathrm{gr} \\
\text { b) } 160 \mathrm{gr} \\
\text { c) } 200 \mathrm{gr}\end{array}$ \\
\hline Shape & $\begin{array}{l}\text { Do you consider the shape of the product } \\
\text { when purchasing a soap? } \\
\text { a) Roses } \\
\text { b) Oval } \\
\text { c) Rectangular } \\
\text { d) Other }\end{array}$ \\
\hline Benefits & $\begin{array}{l}\text { What benefits are you looking for in this } \\
\text { type of product when you buy it? } \\
\text { a) Hydration } \\
\text { b) Cleaning } \\
\text { c) Both } \\
\text { d) Other }\end{array}$ \\
\hline Odor & $\begin{array}{l}\text { What type of aromas do you consider } \\
\text { when purchasing the product? } \\
\text { a) Citrus } \\
\text { b) Florals } \\
\text { c) Relaxing } \\
\text { d) Other }\end{array}$ \\
\hline Packing & $\begin{array}{l}\text { What type of packaging would you like } \\
\text { for a craft soap? } \\
\text { a) Biodegradable } \\
\text { b) Seed paper } \\
\text { c) Other: }\end{array}$ \\
\hline \multicolumn{2}{|c|}{ Dependent variable } \\
\hline \multicolumn{2}{|c|}{ Indicator: market segment preferences. } \\
\hline Dimension & Items \\
\hline \multirow[t]{2}{*}{ Type of skin } & $\begin{array}{l}\text { Do you suffer from dry skin? } \\
\text { A) Yes } \\
\text { b) No }\end{array}$ \\
\hline & $\begin{array}{l}\text { What products do you use to moisturize } \\
\text { the skin? } \\
\text { a) Cream } \\
\text { b) Soap } \\
\text { c) Serum } \\
\text { d) Ampoule } \\
\text { e) Mask } \\
\text { f) Other }\end{array}$ \\
\hline \multirow[t]{2}{*}{ Motivation } & $\begin{array}{l}\text { What would motivate you to purchase a } \\
\text { new moisturizing product? } \\
\text { a) Properties } \\
\text { b) Presentation } \\
\text { c) Quality } \\
\text { d) Price }\end{array}$ \\
\hline & $\begin{array}{l}\text { Would you buy a soap made from corn } \\
\text { that offers you the benefit of moisturizing } \\
\text { and cleansing? } \\
\text { A) Yes } \\
\text { b) No }\end{array}$ \\
\hline
\end{tabular}

Table 3 Determination of indicators, dimensions and items

Source: Own elaoration
Taking into consideration what is contained in Table 3, the data collection instrument (Appendix 1) was designed and validated by applying it to 20 people with the same characteristics of the market segment to which the product is directed. This judgment, added to the review of the literature on which its design was based and the cross-review carried out by the researchers of this project, ensure the initial validity of the instrument. This pre-test allowed correcting the syntax of the items, modifying some terms that were not clear to the respondent and estimating the duration of the surveys.

\section{6) Sample planning.}

The population is made up of economically active people (EAP), who live in the municipality of Metepec in the State of Mexico. According to data from IGECEM (2010) in the municipality of Metepec, Edo. of Mexico there are 91,700 people. For the determination of the sample size, the formula for finite samples of Levin (2004) was applied:

$n=\frac{N(z \alpha)^{2}(p)(q)}{d^{2}(N-1)+(z)^{2}(p)(q)}$

Where:

$\mathrm{N}=$ Total population level of $95 \%$ )

$\mathrm{Z} \alpha=1.96$ squared (taking a confidence $50 \%=0.5)$

$\mathrm{p}=$ product acceptance rate (in this case

$\mathrm{q}=1-\mathrm{p}$ (in this case $1-0.5=0.5)$

$\mathrm{d}=\operatorname{precision}(5 \%)$

$n=\frac{91,700(1.96)^{2}(0.50)(0.50)}{(0.05)^{2}(91,700-1)+(1.96)^{2}(0.5)(0.5)}$

$=383$

\section{7) Data collection}

The sampling was carried out in a simple probabilistic way and a systematic selection of sample elements was carried out, which implies that each element has the same probability of being chosen. This type of selection achieves a proportionate sample. 
It was applied using an interval of 8 people. The survey was carried out in public places attended by the people identified within the market segment: Mall Galerías and Mall Town Square, both located in Metepec, State of Mexico. The application was made on the weekends of September 2019, from 12: 00-16: 00 hours. The filter questions that were used are listed below and to proceed with the application of the questionnaire they should be answered in the affirmative:

\section{You work?}

Do you live in Metepec, State of Mexico?

Do you take care of your skin?

\section{8) Data processing and analysis}

Once the number of surveys was completed, the coding of the answers was executed, setting a unique code for missing data. The data was tabulated, graphed and interpreted. Which are presented in the results section.

\section{9) Formulation of the report}

The results of the market study for corn-based soaps according to the information collected during the month of September 2019 through the application of a survey to a sample of 383 people who are integrated into the labor market, which they care about the care of their skin and that they live in the municipality of Metepec, State of Mexico; were satisfactory since there is acceptance of the product within the market segment with $90 \%$, so the working hypothesis raised in this research is accepted.

\section{Results}

The findings that will be presented in this section are derived from the results obtained from the application of a data collection instrument to determine the acceptance of corn soap. It was applied to 383 people from the municipality of Metepec, State of Mexico; sample determined with a confidence level of $95 \%$ and a sample error or bias of 0.5 with a total population of 91,700. The following graphs show the results obtained in the items considered to know the opinions about this product.

\section{Suffer from dry skin}

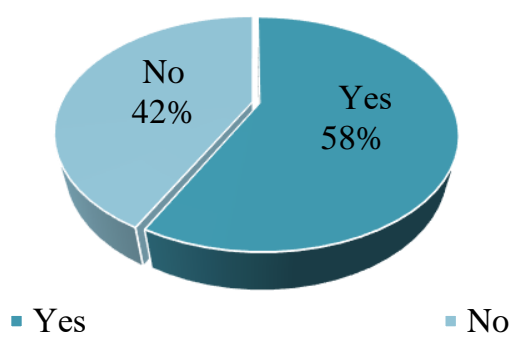

Graphic 1 Dry skin

Source: Own elaoration

Products you use to hydrate your skin

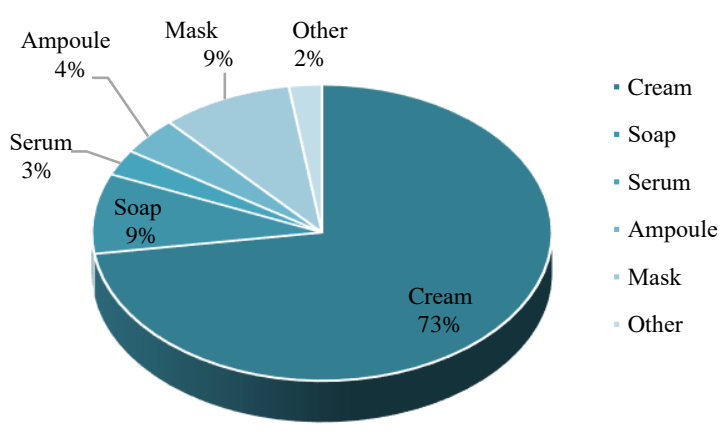

Graphic 2 Products to hydrate the skin Source: Own elaoration

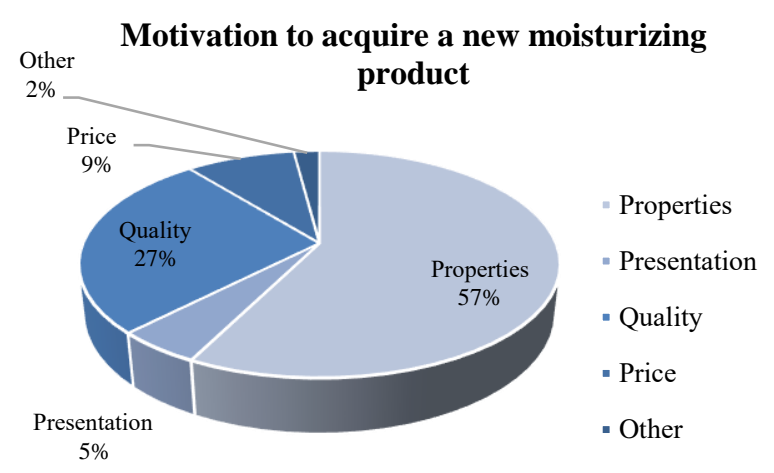

Graphic 3 Motivation to acquire a new moisturizing product

Source: Own elaoration

\section{Use handmade soaps}

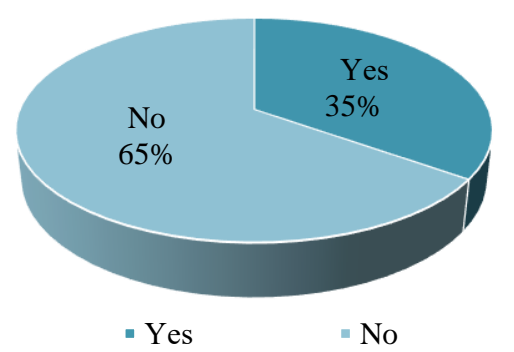

Graphic 4 Use of handmade soaps Source: Own elaoration 


\section{Range of preferred colors for a soap line}

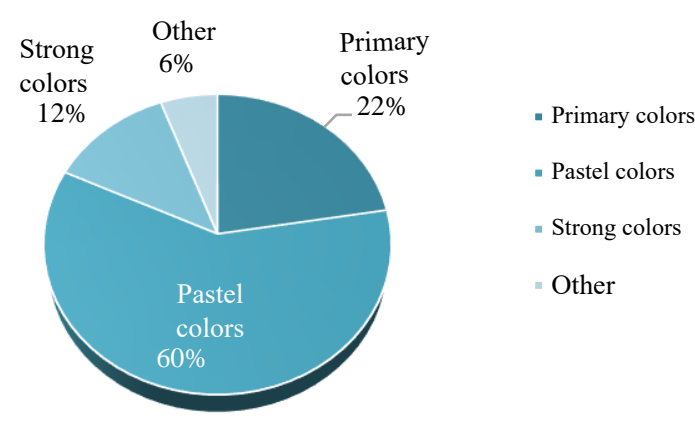

Graphic 5 Favorite colors for a soap line Source: Own elaboration

Presentation in which you would like to find your soap

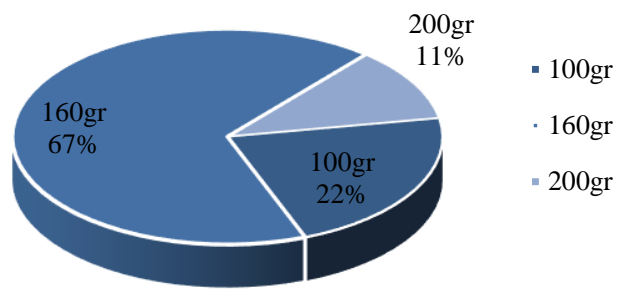

Graphic 6 Preferred presentation in a soap line Source: Own elaoration

Consider the shape of the product when buying soap

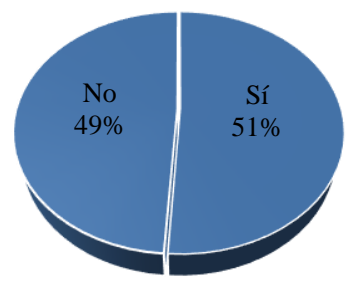

- Yes

- No

Graphic 7 Consider the shape of the soap when purchasing

Source: Own elaoration

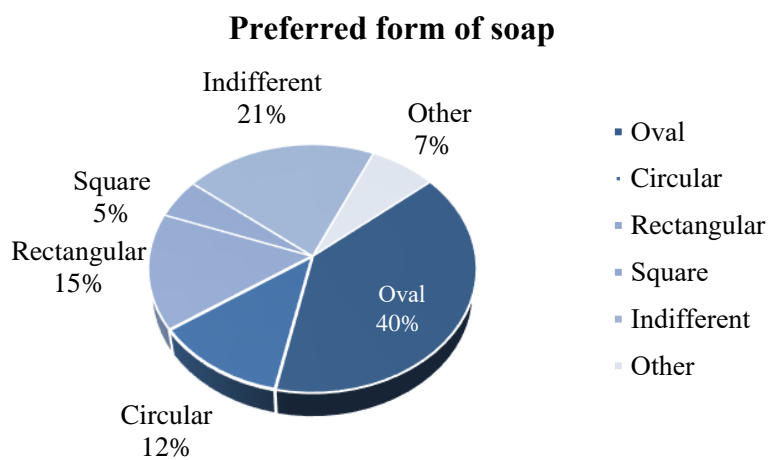

Graphic 8 Preferred form of soap Source: Own elaoration
Benefits you are looking for for the care

of your skin in a soap

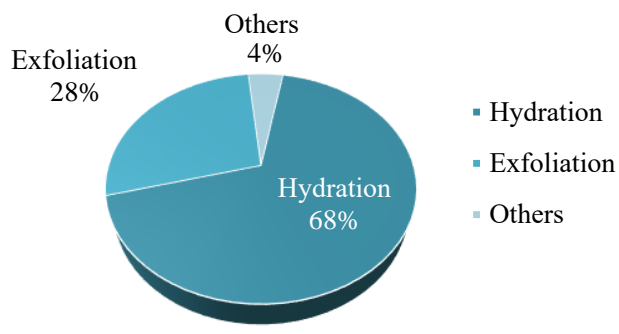

Graphic 9 Benefits for skin care

Source: Own elaoration

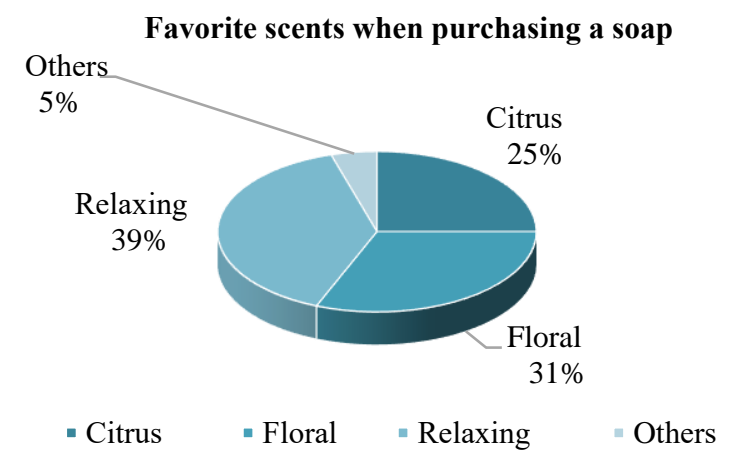

Graphic 10 Favorite scents in a soap

Source: Own elaboration

Place where you would like to purchase the soap

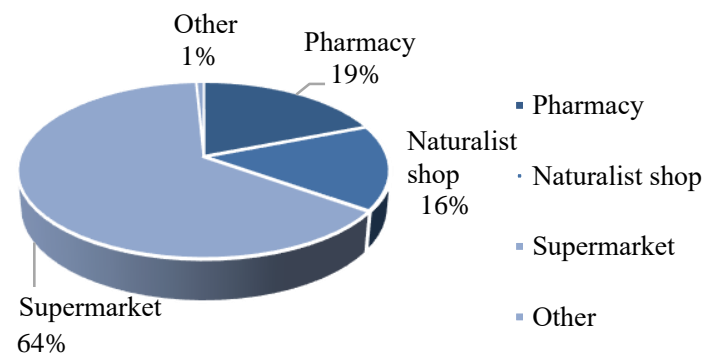

Graphic 11 Place to purchase the soap Source: Own elaoration

Type of packaging you would like for a craft soap

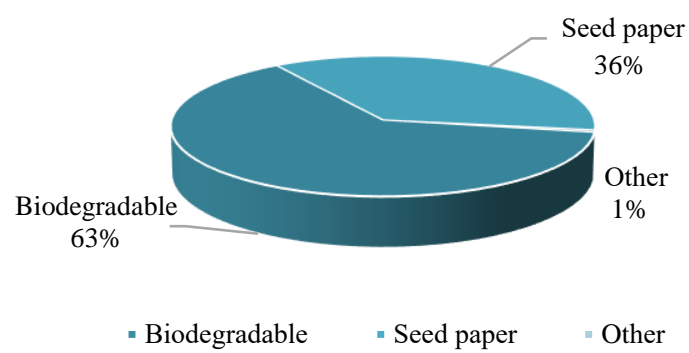

Graphic 12 Preferred packaging type Source: Own elaoration 
I would buy a soap made from corn that offers the benefit of moisturizing and cleaning

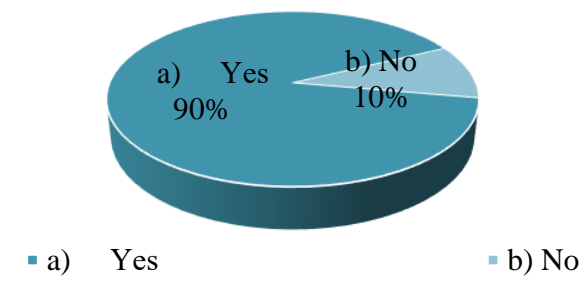

Graphic 13 Purchase a corn-based soap that offers moisturization and cleansing

Source: Own elaoration

Amount you would be willing to pay for corn soap

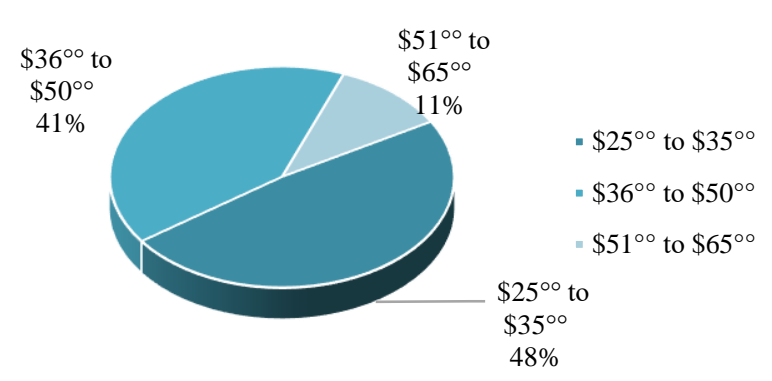

Graphic 14 Amount they would pay for soap Source: Own elaoration

In the evaluation of the results as can be seen in Graphic 1, 58\% of the surveyed population suffers from dry skin and $42 \%$ does not have this problem, corn soap contains vitamins and minerals with astringent properties to balance the levels of oil in the skin, and ingredients with moisturizing properties, so it can satisfy the needs of each client,

With respect to the products they use to hydrate the skin, in Graphic 2, it can be seen that $73 \%$ opt for a cream, and only $9 \%$ for a soap, so that an area of opportunity can be seen in the use of soap to hydrate, as a possible substitute for cream, this being the main competition.

According to Graphic 3, the motivation to acquire a new moisturizing product are the properties, both its ingredients and benefits, as demonstrated by $57 \%$ of those surveyed, followed by the quality of the product with $27 \%$, while presentation and price are factors to take into account with $14 \%$. The use of handmade soap is not widely used in the municipality of Metepec, State of Mexico, as can be seen in Graphic 4, 65\% of the surveyed population does not use soaps of this type, so it can be an area of opportunity for corn soap.
Among the preferred colors in a soap, $60 \%$ of the surveyed population opts for pastel colors, $22 \%$ for primary colors and $12 \%$ strong colors, this information can be displayed in Graphic 5. Regarding the presentation in grams of the soap, in Graphic 6, it can be seen that $67 \%$ of the respondents prefer $160 \mathrm{gr}$ soap, this presentation is the most common for a toilet soap, $22 \%$ opts for a presentation of $100 \mathrm{gr}$ and $11 \%$ of $200 \mathrm{gr}$.

The shape of the soap at the time of purchase is not so significant, $51 \%$ if you consider it and $49 \%$ not, as can be seen in Graphic 7. Regarding the shape of the soap, $40 \%$ of the respondents prefer an oval shape, $21 \%$ are indifferent to the presentation, $15 \%$ and $12 \%$ prefer the rectangular and circular shape respectively, the details of this information can be viewed in the Graphic 8 .

As you can see in Graphic 9, 68\% of those surveyed look for a soap that is moisturizing and $28 \%$ that is exfoliating for their skin care.

Regarding the preferred aromas according to Graphic 10, 39\% of the surveyed population seeks relaxing aromas, $31 \%$ floral essences and $25 \%$ opted for citrus aromas.

Of the 383 people surveyed, $64 \%$ prefer to buy their corn soap in the supermarket, since it is where they buy most of the products for skin care, followed by a pharmacy with a percentage of $19 \%$, while $16 \%$ mentioned that they would like to find it in health food stores, according to the information presented in Graphic 11.

In Graphic 12, it can be seen that potential soap consumers are concerned about the environment and are aware of what a plastic packaging originates in the environment, $63 \%$ chose biodegradable packaging, this result can be used to generate a competitive advantage over companies that manufacture similar products and thus achieve a good position.

Regarding the question, would you buy a soap made from corn that gives you the benefits of moisturizing and cleaning?, the answer is affirmative in $90 \%$ of the surveyed sample. According to information presented in Graphic 13 , it can be concluded that there is a potential market for corn soap. 
It can be seen in Graphic 14 that $48 \%$ of consumers would be willing to pay for corn soap a price that ranges between $\$ 25.00$ and $\$ 35.00$, there is an opportunity to raise the price from $\$$ 36.00 to $\$ 50.00$, however, with a price greater than $\$ 50.00$ drastically decreases the willingness to pay this amount.

\section{Conclusions}

The objective of this research was to define the acceptance of an artisan soap made with corn base for skin care in the market segment located in Metepec, State of Mexico, and according to the evaluation of the results obtained, it can be conclude that the use of artisan soap in Metepec, State of Mexico, is not widely used (65\%), however $90 \%$ of the representative sample would buy a soap made from corn that provides moisturizing and cleaning benefits, the majority of people stated that they suffer from dry skin, hydration being one of the most sought-after benefits in a skin care soap $(68 \%)$, for the aforementioned, the main motivation to acquire a new The product is its properties (57\%), followed by quality $(27 \%)$ and price $(9 \%)$. As mentioned before, corn-based soap is a natural moisturizer for the skin.

Regarding the shape of the soap, $40 \%$ of the people who were surveyed prefer the oval shape and $21 \%$ answered that they are indifferent to the shape, this result is strengthened with the assertion that the shape of the product is not decisive When buying a soap (49\%), however, size is a factor to consider when choosing it since $67 \%$ of people prefer a $160 \mathrm{gr}$ presentation.

With regard to the preferred colors for a soap line, $60 \%$ of the representative sample chose pastel colors; Regarding fragrances, relaxing aromas are the ones with the highest acceptance $(39 \%)$, closely followed by floral aromas $(31 \%)$ and citrus essences $(25 \%)$. The presentation of the packaging is very important and the vast majority of the people surveyed, aware of the environmental problems that exist, prefer a packaging that is biodegradable, which is very appropriate since the product subject of this study is a handmade soap made with a base corn. Another aspect to consider when choosing a product is the price; The results show that the consumer would be willing to pay up to $\$ 50.00$ pesos for corn soap with the characteristics described above, but the majority chose a price ranging from $\$ 25.00$ to $\$ 35.00$ pesos.
As for the place where most consumers want to buy corn-based artisan soap is supermarkets, a small part chose pharmacies or health food stores. It is very important to know the needs and preferences of the consumer, the places where the product can be purchased, as well as a fair price, to determine the viability of a new product on the market; Based on the results obtained in the present work, it is concluded that there is feasibility for the launch of an artisan soap made with corn base for skin care in Metepec, State of Mexico.

\section{Appendix 1}

\section{Data collection instrument}

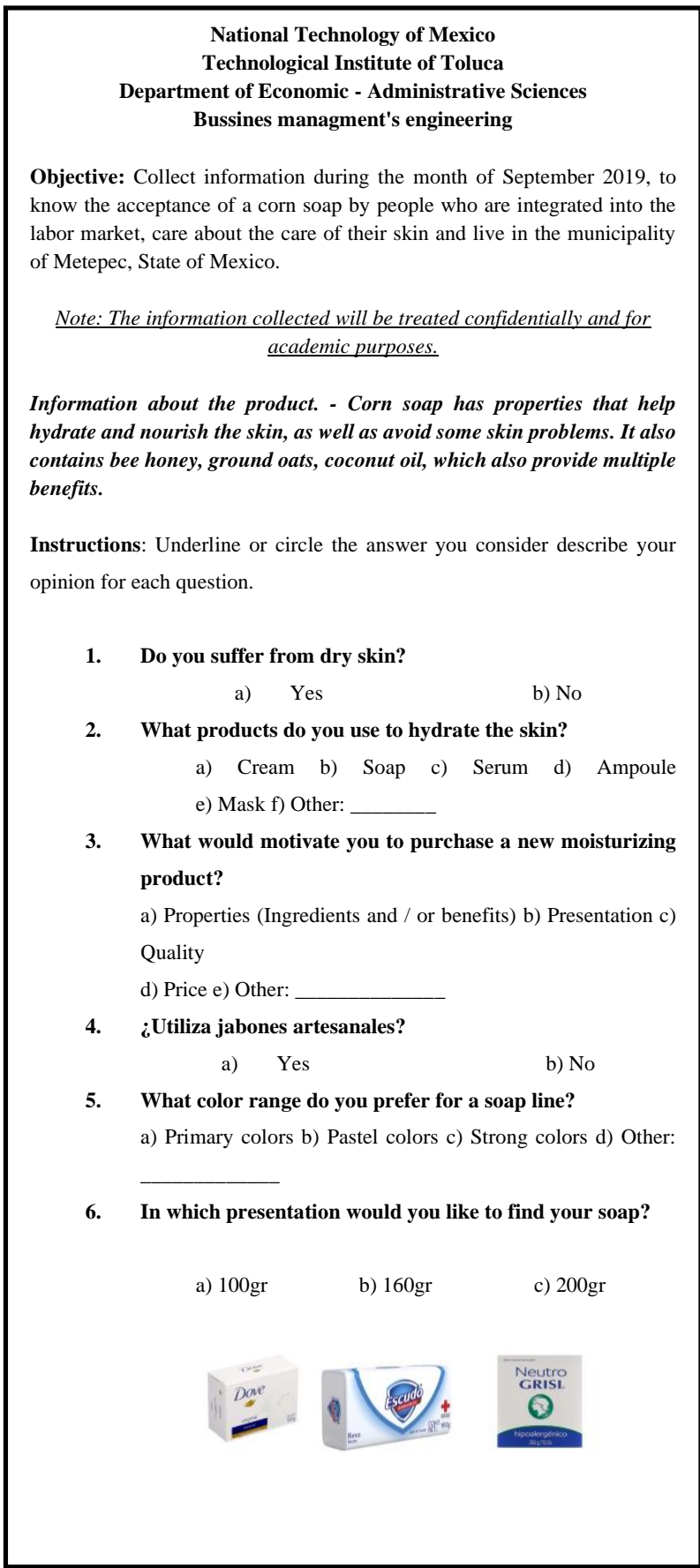

ZENTENO-BONOLA, Ana Luisa, AGUIRRE-BRITO, Dorian, CERVANTES-CARBAJAL, Ana Margarita and GARCÍABARRUETA, Katia Guadalupe. Market research in Metepec, State of Mexico to determine the acceptance of an artisan soap made from corn. RINOE Journal-Business Administration-Marketing; Accounting. 2020 
7. Do you consider the shape of the product when buying soap?

$$
\begin{array}{ll}
\text { a)Yes } & \text { b) No }
\end{array}
$$

8. What shape do you prefer?

a) Oval b) Circular c) Rectangular d) Square e) Indifferent f) Other:

9. 9. What benefits are you looking for specifically in soap for your skin care?

a) Hydration b) Exfoliation c) Others:

10. What scents do you prefer when purchasing the soap? a) Citrus b) Floral c) Relaxing d) Others:

11. Where would you like to buy the soap? a) Pharmacy b) Health food store c) Supermarket d) Other

12. What type of packaging would you like for a craft soap? a) Biodegradable b) Seed paper (post-consumer material with easily germinated seeds) c) Other:

13. Would you buy a soap made from corn that offers you the benefit of moisturizing and cleansing?

$$
\begin{array}{ll}
\text { a)Yes } & \text { b) No }
\end{array}
$$

14. How much would you be willing to pay for corn soap? a) $\$ 25^{\circ \circ}$ a $\$ 35^{\circ \circ} \mathrm{MN} . \quad$ b) $\$ 36^{\circ \circ}$ a $\$ 50^{\circ \circ} \mathrm{MN}$. c) $\$ 51^{\circ \circ}$ a $65^{\circ \circ} \mathrm{MN}$.

OBSERVATIONS:

We appreciate your time and honesty in answering this survey.

$$
\text { ¡Excellent day! (:) }
$$

\section{References}

Abud, L. (2004). El libro de Jabones. Buenos Aires: Albatros.

Alba, G. (2016). El maíz nativo de México: una aproximación crítica desde los estudios rurales. Universidad Autónoma Metropolitana. México: Juan Pablos Editor.

Álvarez, R. et al (2013). Actividad antioxidante de cinco variedades de maíz cultivadas en Campeche, México. Boletín Latinoamericano del Caribe de Plantas Medicinales y Aromáticas, 12 (6), 558-571. ISSN 0717-7917

Barbosa, L. (2012). Estudio de factibilidad para la creación de una microempresa productora y comercializadora de jabón artesanal exfoliante de harina de maíz y efervescente en la Ciudad de Quito (tesis licenciatura). Universidad Central del Ecuador.
Bello, G. Salgado, G. (2007). Plantas medicinales de la comunidad indígena Nuevo San Juan Parangaricutiro, Michoacán, México. Revista Biológicas, 9 (1), 126-138. ISSN 20078145.

Bernal, C. (2016). Metodología de la Investigación. Colombia: Pearson Educación.

Cámara Nacional de la Industria de Aceites, Grasas, Jabones y Detergentes. Recuperado 28 de marzo de 2020 https://www.canajad.org.mx

Cáncer de piel más grave se elevó en México de 300 a $500 \%$ en 10 años. (08 de septiembre de 2019). La Jornada. Recuperado de https://www.jornada.com.mx/

Díaz, G. et al (2011). Cáncer de piel en pacientes menores de 40 años. Experiencia de cuatro años en el Hospital General de México. Gaceta Médica de México, 147, (1), 17-21. ISSN 00163813.

Fernández, N. (2004). Investigación y Técnicas de Mercado. Madrid: ESIC Editorial.

Gallegos, Z. (2017). Plantas medicinales utilizados en el tratamiento de enfermedades de la piel en comunidades rurales de la Provincia de los Ríos Ecuador. Revista Anales de la Facultad de Medicina del Ecuador, 78 (3), 315-321. ISSN 1025-5583

Gómez, Ch., Balcázar, F. (2015). Diseño de un plan de negocios para la creación de una empresa dedicada a la elaboración y exportación de jabón exfoliante de harina de maíz, bajo la certificación ISO 14000 desde el cantón Huaquillas, hacia el mercado de Inglaterra, Ecuador, Machala (tesis de licenciatura). Universidad Técnica de Machala Ecuador.

Gutiérrez, V. (2003). Cáncer de piel. Revista de la Facultad de Medicina UNAM, 46 (4), 166171. ISSN 0026-1742.

Hernández, S. Fernández, C. Baptista, L. (2003). Metodología de la Investigación. México: McGraw-Hill.

Instituto de Información e Investigación Geográfica, Estadística y Catastral del Estado de México (IGECEM). Recuperado $17 \mathrm{de}$ febrero de 2020 
http://iiigecem.edomex.gob.mx/recursos/Estadis tica/PRODUCTOS/AGENDAESTADISTICAB ASICAMUNICIPAL/ARCHIVOS/Metepec.pdf

Instituto Mexicano del Seguro Social. Recuperado 09 de marzo de 2020 https:// imss.gob.mx/sites/all/statics/guiasclinicas/560 GRR.pdf

Instituto Nacional de Estadística y Geografía. Recuperado 09 de marzo de 2020 https:// www.inegi.org.mx/rnm/index.php/catalog/407/ datafile/F5/V128

Jurado, S. et al (2011). Prevalencia del cáncer de piel en tres ciudades de México. Revista Médica del Instituto Mexicano del Seguro Social, 49 (3), 253-258. ISSN 0443-5117.

Kotler, P., Katarjaya, H. y Setiawan, I. (2010). Marketing 3.0. From products to customers to the human spirit. EUA: Wiley

Levin, R., Rubin, D. (2004). Estadística para Administración y Economía. México: Pearson Educación.

Malhotra, N. (2004). Investigación de Mercados. Un enfoque aplicado. México: Pearson Educación.

Moyano, C. (2016). Plan de Negocios. Perú: Editoral Macro.

Núñez, J. (1997). Guía para la preparación de proyectos de servicios públicos municipales. México: Instituto Nacional de Administración Pública. UNAM.

Prieto, H. (2009). Investigación de Mercados. Bogotá: ECOE Ediciones.

Quillahuaman C., Soncco, G. y Vigil, D. (2018). Empresa productora y comercializadora de jabones artesanales naturales Éclat S.R.L. (tesis licenciatura). Universidad Tecnológica del Perú.

Regla, I. et al (2014). La química del jabón y algunas aplicaciones. Revista Digital Universitaria UNAM, 15 (5), 2-12. ISSN 16076079

Salinas, J. (2013). Empresa e iniciativa emprendedora. México: Mc Graw-Hill

Zikmund, G. Babin, J. (2009). Investigación de Mercados. México: Cengage Learning.
ZENTENO-BONOLA, Ana Luisa, AGUIRRE-BRITO, Dorian, CERVANTES-CARBAJAL, Ana Margarita and GARCÍABARRUETA, Katia Guadalupe. Market research in Metepec, State of Mexico to determine the acceptance of an artisan soap made from corn. RINOE Journal-Business Administration-Marketing; Accounting. 2020 